https://doi.org/10.22319/rmcp.v11i3.5242

Artículo

\title{
Uso de una PCR anidada para el diagnóstico del virus de la necrosis pancreática infecciosa (VNPI) en truchas de campo
}

Catalina Tufiño-Loza ${ }^{a}$

José Juan Martínez-Maya ${ }^{\text {a }}$

Amaury Carrillo-González b

Diana Neria-Arriaga $^{c}$

Celene Salgado-Miranda ${ }^{\mathrm{d}}$

Edith Rojas-Anaya ${ }^{\mathrm{e}}$

Elizabeth Loza-Rubio ${ }^{\mathrm{e}^{*}}$

a Universidad Nacional Autónoma de México. Facultad de Medicina Veterinaria y Zootecnia, Ciudad de México, México.

${ }^{\mathrm{b}}$ Universidad del Valle de México, Campus Toluca, Estado de México, México.

c SENASICA, Ciudad de México, México.

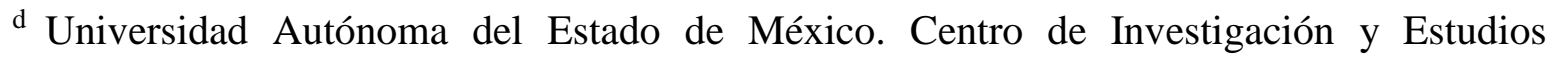
Avanzados en Salud Animal, Estado de México, México.

${ }^{\mathrm{e}}$ INIFAP. Centro Nacional de Investigaciones Disciplinarias en Salud Animal e Inocuidad.

Carretera México-Toluca km 15.5, Colonia Palo Alto, Ciudad de México, México.

* Autor de correspondencia: loza.elizabeth@inifap.gob.mx, eli_rubio33@hotmail.com 


\section{Resumen:}

El aislamiento en cultivo celular es el método principal para el diagnóstico del virus de la necrosis pancreática infecciosa (VNPI). Aunque es un método confiable, resulta costoso y conlleva tres semanas en proporcionar un resultado. Para disminuir el tiempo en el diagnóstico y aumentar la sensibilidad para la detección del VNPI, el objetivo del presente estudio fue establecer y evaluar el uso de una PCR anidada (PCRa) para un diagnóstico rápido del VNPI. Para ello, se diseñaron dos pares de iniciadores basados en secuencias mexicanas. El primer par (RT-PCR) amplificó un producto de 682 pb y el segundo par (PCRa) 229 pb del gen VP2. Posteriormente, se infectaron 70 crías de truchas arcoíris (Oncorhynchus mykiss) con la cepa virulenta MEX3-CSM-05 a una dosis de 1 X10 5.8 DICC50\%/0.02 ml. De cada organismo se colectó el riñón, el bazo, los sacos pilóricos, el hígado, el intestino y las branquias. Para evaluar las pruebas, se utilizaron 26 truchas adultas clínicamente sanas de granjas comerciales del Estado de México. La frecuencia de detección del VNPI mediante RT-PCR en las branquias fue de $87.1 \%$, en el hígado $61.4 \%$, en los sacos pilóricos $61.4 \%$, en el riñón 58.6\%, en el intestino $35.7 \%$ y en el bazo $32.9 \%$ $(P<0.05)$. Las muestras negativas a la RT-PCR resultaron positivas en la PCRa. Asimismo, se mostraron positivas las muestras de los órganos de las truchas de campo. En conclusión, la RT-PCR tuvo menor sensibilidad que la PCRa, la cual mostró una sensibilidad del 100\%. Por lo tanto, la PCRa es mejor para un diagnóstico confiable del VNPI en peces infectados y enfermos.

Palabras clave: VNPI, PCR anidada, Trucha arcoíris, Diagnóstico.

Recibido: 30/01/2019

Aceptado: 09/12/2019

\section{Introducción}

El crecimiento constante de la industria acuícola ha generado mayor incidencia y propagación de enfermedades, principalmente aquellas generadas por virus debido a su rápida dispersión y alto grado de infección. La necrosis pancreática infecciosa (NPI) es una enfermedad sistémica aguda que afecta principalmente a peces de la familia de los salmónidos. Causa una mortalidad elevada en alevines y crías, y los peces sobrevivientes eliminan el virus toda su vida ${ }^{(1,2)}$. El agente etiológico de la NPI pertenece a la familia Birnaviridae, género Aquabirnavirus ${ }^{(3,4)}$. Es un virus no envuelto, con una cápside en forma de icosaedro y un diámetro aproximado de $60 \mathrm{~nm}^{(5)}$. Su genoma está compuesto por dos segmentos de ácido ribonucleico (ARN) de doble cadena ${ }^{(1)}$. El virus de la NPI (VNPI) se 
caracteriza por su gran variabilidad antigénica y genotípica. Su presencia ha sido notificada en salmónidos silvestres y de cultivo en diferentes países en todos los continentes, por lo que se considera una enfermedad de distribución mundial ${ }^{(6,7)}$. Los brotes de la NPI se deben con frecuencia a las importaciones y la venta de huevo oculado y crías infectadas ${ }^{(8)}$. En México, esta enfermedad fue identificada en el año 2000 en crías de trucha arcoíris (Oncorhynchus mykiss) importadas de Estados Unidos de América ${ }^{(9)}$. En el 2009, se reportó una prevalencia nacional del $11.9 \%$ y una diseminación en el $62.5 \%$ en las principales entidades trutícolas nacionales. Sin embargo, no se ha calculado el impacto económico que ha provocado el virus desde su identificación en el 2002 a la fecha ${ }^{(10)}$.

El aislamiento viral en líneas celulares de peces, como fibroblasto de alevín Lepomis macrochirus (BF-2), células embrionarias de salmón Chinook (CHSE- 214) o fibroblastos de gónada de trucha arcoíris (RTG-2), seguido de su identificación inmunológica mediante inmunofluorescencia en peces aparentemente sanos, es el diagnóstico sugerido por la Organización Mundial de Sanidad Animal ${ }^{(7)}$. Sin embargo, a pesar de ser un método confiable, resulta costoso y su realización conlleva al menos tres semanas para confirmar un resultado como negativo ${ }^{(11,12)}$. Además, ese tiempo es crítico en la diseminación del virus, debido a la rápida dispersión en corrientes lóticas, lo que puede causar pérdidas económicas considerables ${ }^{(2,13)}$. Existen otras pruebas para la identificación del virus como son: la inmunohistoquímica y ELISA (ensayo por inmuno-absorción ligado a enzimas) para la detección del antígeno ${ }^{(7)}$. Sin embargo, problemas como la dependencia en la importación de estas pruebas y anticuerpos monoclonales, la autofluorescencia de los tejidos de los peces, un título viral alto, la dificultad para obtener muestras frescas de tejidos de peces y la reacción cruzada de los anticuerpos son las limitantes más comunes para el uso universal y rutinario de las técnicas mencionadas ${ }^{(14,15)}$.

Por lo anterior, se han propuesto varios protocolos para una identificación eficiente y rápida del VNPI a partir de cultivos celulares infectados o de muestras de tejidos, mediante el uso de la reacción de transcripción reversa de la cadena de la polimerasa (RT-PCR) y algunas de sus variantes ${ }^{(16-24)}$. Con el propósito de disminuir el tiempo de diagnóstico para implementar diversas estrategias en el control de la NPI y prevenir su exposición en las unidades de producción, el objetivo del presente estudio fue establecer y evaluar el uso de una PCR anidada (PCRa) con iniciadores diseñados usando secuencias de aislamientos mexicanos, para el diagnóstico del VNPI a partir de tejidos de truchas infectadas experimentalmente y de truchas clínicamente sanas cultivadas en unidades de producción acuícola. 


\section{Material y métodos}

\section{Línea celular}

Se empleó la línea celular BF-2 de Lepomis macrochirus (ATCC@ CCL 91) para la replicación de la cepa virulenta MEX2-CSM-05(25). La línea celular BF-2 se propagó a $20{ }^{\circ} \mathrm{C}$, en medio Leibovitz (L-15) (In vitro, México) suplementado con suero fetal bovino al 10\% (SFB) (Biowest, México) $100 \mathrm{IU} / \mathrm{ml}$ de penicilina, $100 \mu \mathrm{g} / \mathrm{ml}$ de estreptomicina y $0.25 \mu \mathrm{g} / \mathrm{ml}$ de anfotericina B (In vitro, México).

\section{Virus}

La cepa virulenta MEX2-CSM-05 del VNPI notificada por Salgado-Miranda et al ${ }^{(25)}$ se replicó en monoestratos confluentes de la línea celular BF-2 a $15{ }^{\circ} \mathrm{C}$ en medio Leibovitz (L-15) (In vitro, México) suplementado con suero fetal bovino al 2\% (SFB) (Biowest, México). Una vez que se observó el efecto citopático (ECP) que consistió en la pérdida gradual del monoestrato y redondeamiento de la células, a las $72 \mathrm{~h}$ post-infección se congelaron las botellas de cultivo a $-20{ }^{\circ} \mathrm{C}$ y descongelaron en dos ocasiones, posteriormente se recolectó el medio con las células en suspensión y se centrifugó a 1,200 $\mathrm{g}$ por 15 min a $4{ }^{\circ} \mathrm{C}^{(7)}$ para la obtención del sobrenadante, a partir del cual se determinó el título viral (dosis infectiva en cultivo celular, DICC) mediante el método de Reed y Muench.

\section{Truchas}

Para el estudio experimental, se adquirieron 100 crías de truchas arcoíris (O. mykiss) del Centro Acuícola El Zarco de la Comisión Nacional de Acuacultura y Pesca (CONAPESCA), con una talla promedio de $3 \mathrm{~cm}$, un peso promedio de $1 \mathrm{~g}$ y 480 gradosdías (valor que se obtiene multiplicando la edad en días por el promedio de la temperatura en grados centígrados durante la vida útil) ${ }^{(26)}$. Para evaluar la prueba, se adquirieron 26 truchas arcoíris (O. mykiss) adultas clínicamente sanas provenientes de unidades de producción comerciales en el Estado de México. La evaluación clínica de los peces consistió en una evaluación de su comportamiento, así como de su apariencia externa, en ella se observó un nado normal de la especie, a contracorriente, en donde responde a ruidos y estímulos (reacción de fuga). La coloración de los peces se observó normal, amarillo verdoso, vientre blanco y puntos negros en la parte dorsal y en las aletas. También se observó en ellas una piel suave, sin hematomas y aletas íntegras. En las truchas provenientes del centro acuícola se determinó su estatus sanitario previo al inicio del experimento mediante el análisis de 10 organismos para evaluar la presencia de bacterias, 
parásitos y el virus de la necrosis pancreática infecciosa (VNPI) por aislamiento y PCR en el Laboratorio de Sanidad Acuícola del Centro de Investigación y Estudios Avanzados en Salud Animal de la Universidad Autónoma del Estado de México, cuyo resultado fue negativo para las bacterias, parásitos y el VNPI. De esta forma se determinó la utilización de animales clínicamente sanos para el experimento. En las truchas provenientes de las unidades de producción comerciales del Estado de México, únicamente se realizó la evaluación de comportamiento y apariencia externa, ya que éstas fueron utilizadas para evaluar la PCR anidada para la detección del VNPI. Los organismos se mantuvieron en estanques de polipropileno con $60 \mathrm{~L}$ de agua en re-circulación, con un fotoperiodo de $12 \mathrm{~h}$ de luz/ $12 \mathrm{~h}$ de oscuridad, una temperatura ambiental de entre $14-17{ }^{\circ} \mathrm{C}$ y alimentadas con producto comercial, suministrando el 3\% de su biomasa total al día.

\section{Infección experimental con VNPI}

A partir de las 100 truchas arcoíris provenientes del Centro Acuícola se inocularon 70 por vía intraperitoneal con 1 X10 ${ }^{5.8}$ DICC 50\%/0.02 ml de la cepa virulenta MEX3-CSM-05. Los 30 organismos restantes no fueron inoculados y se mantuvieron en otro estanque como control negativo a la detección del VNPI en tejido mediante la PCRa. Posterior a la inoculación, se realizó un examen clínico diariamente para identificar y seguir el curso de la enfermedad con los signos clínicos, que consistieron en la disminución del apetito, anorexia, hiperpigmentación, distención abdominal, exoftalmos moderado y nado errático

en espiral. Cuando los peces mostraron signos clínicos muy avanzados se les practicó la eutanasia por sobreexposición a la anestesia con tricaína metanosulfonato (MS-222) (Sigma-Aldrich, 886-86-2, EUA) a una concentración de $50 \mu \mathrm{g} / \mathrm{ml}^{(27)}$. Después de aplicar la eutanasia en los peces, se recolectaron los siguientes órganos: riñón, bazo, sacos pilóricos, hígado, intestino y branquias, los cuales fueron conservados a $-80^{\circ} \mathrm{C}$. Adicionalmente, y en las mismas fechas se realizó la eutanasia de dos truchas del estanque del control negativo cada día, para recolectar los órganos mencionados.

Los peces provenientes de las unidades de producción comerciales del Estado de México, a su llegada al laboratorio se realizó la eutanasia para la recolección de los órganos. Todos los procedimientos que involucraron el manejo de los animales se realizaron de acuerdo a los lineamientos establecidos por el Comité de Bioética para el cuidado y uso razonable de los animales de experimentación en proyectos de investigación (autorización no. CBCURAE-006) en el Centro Nacional de Investigación Disciplinaria en Salud Animal e Inocuidad del Instituto Nacional de Investigaciones Forestales, Agrícolas y Pecuarias, donde se realizaron todos los procedimientos. 


\section{Extracción de ARN y síntesis de ADNc}

Los órganos se maceraron y homogeneizaron con solución salina fosfatada (PBS) estéril a un $\mathrm{pH} 7.2$, de estos se tomaron $250 \mu \mathrm{l}$ para la extracción de ARN total con Trizol (Invitrogen, 15596018, EUA), siguiendo las instrucciones del fabricante. El ARN se resuspendió en agua libre de DNasas y RNasas. La síntesis de ADNc se realizó con el kit M-MLV Reverse Transcriptase, oligo (dT) $)_{12-18}(0.5 \mu \mathrm{g} / \mu \mathrm{l})$ (Invitrogen, EUA). El ARN se incubó con $1 \mu \mathrm{l}$ de oligo $(\mathrm{dT})_{12-18}(0.5 \mu \mathrm{g} / \mu \mathrm{l})$ y $1 \mu \mathrm{l} 10 \mathrm{mM}$ de dinucleósidos trifosfato (dNTP) durante 5 min a $65{ }^{\circ} \mathrm{C}$. Después de la incubación, se agregaron $4 \mu \mathrm{l}$ de $5 \mathrm{X}$ first strand buffer, $1 \mu \mathrm{l}$ de $0.1 \mathrm{M}$ dithiothreitol (DTT) y $1 \mu \mathrm{l}$ de MML-V Reverse Transcriptase, se mezcló y se incubó durante $1 \mathrm{~h}$ a $50{ }^{\circ} \mathrm{C}$. Posteriormente la reacción se inactivó a $70{ }^{\circ} \mathrm{C}$ durante 15 min y se almacenó a $-20^{\circ} \mathrm{C}$, hasta su uso.

\section{Iniciadores}

Los iniciadores para la detección de un fragmento del gen VP2 del VNPI y del gen constitutivo en este estudio aparecen en el Cuadro $1^{(10,28)}$. Estos se sintetizaron en el Instituto de Biotecnología de la Universidad Nacional Autónoma de México (Cuernavaca, Morelos, México).

Cuadro 1: Secuencia de iniciadores para detectar el gen VP2 del VNPI y del gen constitutivo EF- $\alpha$.

\begin{tabular}{|c|c|c|c|c|c|}
\hline & Secuencia & Posición & $\begin{array}{l}\text { No. acceso } \\
\text { GenBank }\end{array}$ & $\begin{array}{l}\text { Tamaño } \\
\text { (pb) }\end{array}$ & $\mathbf{T a}$ \\
\hline \multirow{2}{*}{ RT-PCR } & For 5' CCGAATCAGGAAGTGGMMTTCTTG 3' & $137-160$ & & \multirow{2}{*}{689} & \multirow{2}{*}{$60^{\circ}$} \\
\hline & Rev 5' GTGACCACKGGGACGTCATTGTC 3' & $796-818$ & & & \\
\hline \multirow[b]{2}{*}{ PCRa } & For 5', TCACCGTCCTGAATCTACCAAC 3, & $482-503$ & & \multirow[b]{2}{*}{229} & \multirow[b]{2}{*}{$65^{\circ}$} \\
\hline & Rev 5' GTTGTGGAGTTSACGATGTCSGC 3' & $688-710$ & & & \\
\hline \multirow[b]{2}{*}{$\mathrm{EF}-\alpha$} & For -5 'GATCCAGAAGGAGGTCACCA 3' & $561-583$ & \multirow[b]{2}{*}{ AF498320 } & \multirow[b]{2}{*}{150} & \multirow[b]{2}{*}{$55^{\circ}$} \\
\hline & Rev -5' TTACGTTCGACCTTCCATCC 3' & $694-713$ & & & \\
\hline
\end{tabular}

\section{PCR y PCRa}

Para la amplificación de todos los productos de PCR se utilizó el kit Dream Taq DNA Polymerase (Thermo Scientific, EUA) y las reacciones se prepararon con una concentración final de $2 \mathrm{mM} \mathrm{MgCl}, 0.2 \mathrm{mM}$ de dNTP's Mix, $0.2 \mathrm{mM}$ de cada iniciador (sentido y antisentido) descritos anteriormente, $5 \mu \mathrm{l}$ de ADNc de cada muestra y $1.25 \mathrm{U}$ de 
ADN polimerasa. La amplificación de la PCR se llevó a cabo bajo las siguientes condiciones: desnaturalización inicial de $95^{\circ} \mathrm{C}$ durante $1 \mathrm{~min}$, seguida de 35 ciclos de desnaturalización a $95{ }^{\circ} \mathrm{C}$ por $30 \mathrm{~s}$, alineación a $60{ }^{\circ} \mathrm{C}$ durante $30 \mathrm{~s}$, una extensión a $72{ }^{\circ} \mathrm{C}$ por $30 \mathrm{~s}$; y se agregó una extensión final a $72^{\circ} \mathrm{C}$ durante $7 \mathrm{~min}$. Posteriormente, el templado que se utilizó para la PCRa fue el producto de la PCR anterior y su amplificación se realizó bajo las mismas condiciones antes mencionadas, excepto que la temperatura de alineación fue de $65{ }^{\circ} \mathrm{C}$. Los productos de PCR y PCRa fueron analizados mediante electroforesis en un gel de agarosa al 1\% en buffer TAE (40 mM Tris, $20 \mathrm{mM}$ Ácido acético, 2 mM EDTA), teñido con GelRed (Biotium, EUA) y visualizado en el fotodocumentador Quantity One 1-D Analysis System (Bio-Rad, EUA).

\section{Análisis estadístico}

La frecuencia de órganos positivos a la RT-PCR y PCRa de truchas infectadas experimentalmente se analizó en tablas de contingencia y a través de una prueba de Jicuadrada $^{(25)}$, adicionalmente, se evaluó la sensibilidad y especificidad de cada prueba (Cuadro 2). La proporción de muestras positivas a la RT-PCR en cada órgano se compararon con la prueba estadística de múltiples proporciones tipo Tukey con transformación angular en donde se consideró una significancia estadística de $P<0.05^{(29)}$.

Cuadro 2: Generación de las celdas con las que se realizan los cálculos de sensibilidad y especificidad

\begin{tabular}{|c|c|c|c|c|}
\hline \multicolumn{4}{|c|}{ Estado de salud de los peces } & \multirow{4}{*}{$\begin{array}{l}\text { Sensibilidad = VP } /(\mathrm{VP}+\mathrm{FN}) \\
\text { Especificidad }=\mathrm{VN} /(\mathrm{FP}+\mathrm{VN})\end{array}$} \\
\hline \multirow{3}{*}{$\begin{array}{l}\text { Prueba } \\
\text { molecular }\end{array}$} & & Infectados & Sanos & \\
\hline & Positivo & $\begin{array}{l}\text { Verdaderos } \\
\text { positivos (VP) }\end{array}$ & $\begin{array}{l}\text { Falsos } \\
\text { positivos } \\
\text { (FP) }\end{array}$ & \\
\hline & Negativo & $\begin{array}{l}\text { Falsos } \\
\text { negativos }(\mathrm{FN})\end{array}$ & $\begin{array}{l}\text { Verdaderos } \\
\text { negativos } \\
(\mathrm{VN})\end{array}$ & \\
\hline
\end{tabular}

\section{Resultados}

Las truchas infectadas experimentalmente comenzaron a mostrar signos clínicos sugerentes a la NPI a partir del día 7 y hasta el día 11 post-inoculación (pi) (Cuadro 3). La mortalidad se observó a partir del día 7 pi, alcanzando el $100 \%$ de la mortalidad al día 11 pi. Los principales hallazgos de la necropsia en truchas inoculadas fueron: ausencia de alimento en 
el estómago, el hígado se mostró pálido y con presencia de moco en el intestino, mientras que, las truchas provenientes de las unidades de producción se observaron clínicamente sanas y sin lesiones a la necropsia.

Cuadro 3: Cinética de la presentación de los signos clínicos en las truchas arcoíris inoculadas experimentalmente con la cepa MEX2-CSM-05

\begin{tabular}{ll}
\hline Día post-desafío & Descripción de los signos clínicos \\
\hline $1-6$ & No se observaron signos \\
& $\begin{array}{l}\text { Anorexia, hiperpigmentación, disminución del apetito, distención } \\
\text { abdominal, exoftalmos moderado, nado errático en espiral en } \\
7\end{array}$ \\
& $\begin{array}{l}\text { algunas truchas. } \\
\text { Incremento de la presentación del nado errático en espiral en más } \\
\text { truchas, además de hiperpigmentación, anorexia, distención } \\
\text { abdominal. } \\
\text { Aumento en el nado errático en espiral en más truchas, además de } \\
\text { hiperpigmentación, anorexia, distención abdominal. Algunos } \\
\text { organismos solo permanecían en el fondo. } \\
\text { Nado errático en espiral, hiperpigmentación, anorexia, distención } \\
\text { abdominal. } \\
\text { Nado errático en espiral, hiperpigmentación, anorexia, distención } \\
\text { abdominal. }\end{array}$ \\
\hline
\end{tabular}

Los resultados obtenidos de la RT-PCR en los diferentes órganos de las truchas inoculadas experimentalmente permitieron lograr la detección del VNPI en diferentes proporciones. Los órganos que mostraron mayor frecuencia de detección del virus fueron las branquias (87.1 \%), el hígado $(61.4 \%)$, los sacos pilóricos $(61.4 \%)$ y el riñón $(58.6 \%)(P<0.05)$. Por otro lado, los que registraron la menor frecuencia de detección de VNPI fueron: el intestino $(35.7 \%)$ y bazo (32.9 \%) (Cuadro 4) $(P<0.05)$. Sin embargo, al realizar la PCRa en estas últimas muestras sí se detectó un producto de $229 \mathrm{pb}$, el cual previamente fue enviado a secuenciar y se corroboró que correspondiera al VNPI. Los órganos de las truchas recolectadas del estanque control fueron negativas a la amplificación de la PCRa. 
Cuadro 4: Detección por RT-PCR y PCRa del gen VP2 del VNPI en los órganos de truchas arcoíris inoculadas con la cepa MEX2-CSM-05

\begin{tabular}{lllll}
\hline \multirow{2}{*}{ Órgano } & \multicolumn{2}{l}{ RT-PCR } & & PCRa \\
\cline { 2 - 5 } & $\begin{array}{l}\text { Muestras } \\
\text { positivas }\end{array}$ & $\%$ & $\begin{array}{l}\text { Muestras } \\
\text { positivas }\end{array}$ & $\%$ \\
\hline Riñón & $41 / 70$ & 58.6 & $29 / 70$ & 41.4 \\
Hígado & $43 / 70$ & 61.4 & $27 / 70$ & 38.6 \\
Sacos pilóricos & $43 / 70$ & 61.4 & $27 / 70$ & 38.6 \\
Intestino & $25 / 70$ & 35.7 & $45 / 70$ & 64.3 \\
Branquias & $61 / 70$ & 87.1 & $9 / 70$ & 12.9 \\
Bazo & $23 / 70$ & 32.9 & $47 / 70$ & 67.1 \\
\hline
\end{tabular}

Con base en los resultados anteriores, la RT-PCR mostró menor sensibilidad que la PCRa en cada órgano analizado (Cuadro 5); sin embargo, la especificidad fue del $100 \%$; mientras que la PCRa, mostró una sensibilidad y especificidad del $100 \%$. Los órganos de las truchas provenientes de las unidades de producción comerciales del Estado de México amplificaron únicamente al utilizar la PCRa, la frecuencia de detección fue del $100 \%$.

Cuadro 5: Sensibilidad de la RT-PCR

\begin{tabular}{lll}
\hline Órgano & Sensibilidad (\%) (IC) & Especificidad (\%) \\
\hline Riñón & $58.6(47.0,70.1)$ & 100 \\
Hígado & $61.4(50.0,72.8)$ & 100 \\
Sacos pilóricos & $61.4(50.0,72.8)$ & 100 \\
Intestino & $35.7(24.5,46.9)$ & 100 \\
Branquias & $87.1(79.3,95.0)$ & 100 \\
Bazo & $32.9(21.9,43.9)$ & 100 \\
\hline \multicolumn{2}{c}{ IC= intervalos de confianza $95 \%}$.
\end{tabular}

\section{Discusión}

Actualmente, muchas enfermedades de peces usan técnicas moleculares para un diagnóstico rápido, sensible y específico. Esto ha permitido la detección oportuna de una gran cantidad de agentes infecciosos. En consecuencia, se han logrado desarrollar, implementar y mejorar las medidas de prevención y control de muchas enfermedades.

Desde su detección inicial en la trucha Salvenilus fontinalis, el VNPI ha sido identificado en una amplia variedad de peces y especies invertebrado, pero con gran impacto en los 
salmónidos con distribución mundial ${ }^{(30,31)}$. Aunque se ha demostrado que actualmente el virus está presente en casi todos los estados productores de trucha del país ${ }^{(32)}$, los casos reportados con enfermedad clínica son pocos, esto puede deberse a que los aislados mexicanos del VNPI están relacionados con la cepa VR-299 de origen norteamericano inicialmente reportada por Ortega $e t a l^{(9)}$, la cual es considerada de baja virulencia ${ }^{(33)}$. Por esta razón, para este estudio, se diseñaron dos pares de iniciadores específicos para detectar las cepas mexicanas del VNPI que circulan en México y la cepa de referencia $\mathrm{Sp}^{(10)}$, ya que debido a la variabilidad antigénica de este virus se ha demostrado que los iniciadores que reconocen cepas de otras partes del mundo no reconocen las cepas actualmente circulantes en el país ${ }^{(21,34)}$.

En los últimos años, las técnicas moleculares como la PCR se han utilizado ampliamente para la detección de virus de peces ${ }^{(9,30)}$. El uso de la RT-PCR se ha aplicado en la detección del VNPI debido a su precisión, rapidez y alta sensibilidad ${ }^{(18,19,21,34)}$. Esta técnica se puede aplicar específicamente para la detección del genoma viral sin haber realizado un aislamiento viral previo, esto se llevó a cabo en Irán, en donde mediante la RT-PCR se confirmó la presencia del VNPI por primera vez en las granjas piscícolas de trucha arcoíris de la provincia de Fars, cuyo aislado se asemeja a la cepa $\mathrm{Ab}^{(35)}$.

La aplicación de RT-PCR se ha descrito para detectar al genoma del VNPI de cultivos celulares, de peces inoculados experimentalmente, y de peces, crustáceos y moluscos infectados de manera natural ${ }^{(35)}$. La infección por el VNPI es letal en salmónidos jóvenes, aunque este virus se puede aislar en diferentes órganos de los peces infectados en todos los rangos de edad ${ }^{(13)}$. En el presente estudio, la PCRa mostró ser eficiente en la detección de un fragmento del genoma del VNPI tanto en las crías de trucha arcoíris como en las truchas provenientes de granjas comerciales, las cuales son de mayor peso y edad.

Aunque el aislamiento de los birnavirus acuáticos de las especies aparentemente sanas puede ser común, se ha demostrado que la infección por VNPI puede no ser detectada aún cuando las muestras han sido examinadas por cultivo celular ${ }^{(36,37)}$. Varios trabajos mostraron que la RT-PCR era más sensible que el aislamiento del cultivo celular para la detección del $\mathrm{VNPI}^{(38)}$. La RT-PCR en tiempo real es ligeramente más sensible que el aislamiento viral en cultivo celular, este último es recomendado por la OIE para detectar el VNPI de peces portadores, los cuales han demostrado tener bajas concentraciones de virus en riñones, lo que puede limitar su detección por aislamiento viral ${ }^{(36,39)}$.

De acuerdo con Milne et al ${ }^{(13)}$, los títulos relativamente altos del virus están presentes en los peces con signología avanzada por VNPI. Esto podría hacer más fácil la detección del genoma del virus por RT-PCR en punto final como una técnica molecular cualitativa. Sin embargo, como se mostró en nuestro estudio, un fragmento del genoma del VNPI fue detectado en un cierto porcentaje de los peces infectados experimentalmente en el ensayo 
de RT-PCR, dependiendo del órgano evaluado. Sin embargo, al realizarse el ensayo de la PCRa en las muestras negativas mostraron ser positivas, con un incremento de sensibilidad al $100 \%$. Esto mismo se observó en las muestras de truchas juveniles provenientes de las unidades de producción comerciales, que se mostraban aparentemente sanas y resultaron ser positivas en la PCRa. Esto podría deberse a que la concentración de partículas virales en los portadores asintomáticos a menudo son bajas, lo cual dificulta la detección del virus por medio de la RT-PCR ${ }^{(13)}$.

Los resultados obtenidos en este estudio en peces adultos determinaron que los animales testados podrían ser portadores sanos, esto sucede cuando los peces sobreviven a la infección por VNPI y al continuar con su ciclo productivo contribuyen con la transmisión vertical del virus a través de las ovas o semen. Estos portadores asintomáticos pueden no mostrar signos clínicos aparentes o cambios patológicos ${ }^{(40,41)}$ y dependiendo del progreso de la enfermedad a través del tiempo y/o de la respuesta inmunológica de cada espécimen, pueden no observarse cambios macro y microscópicos en los diferentes órganos de los peces. Sin embargo, los salmónidos persistentemente infectados con el VNPI son una potencial fuente de dispersión de la enfermedad y potencialmente detectables por la PCR. Cabe destacar que es muy probable que los casos detectados de VNPI mediante la PCRa se encuentren relacionados con cepas de baja virulencia, y por tanto no causen afectación significativa en la producción de trucha, sin embargo el riesgo potencial de la introducción y diseminación de otras cepas de VNPI también puede deberse a la importación de huevo oculado de los EUA principalmente, además de algunos países de Europa, África y Sudamérica que también son proveedores ${ }^{(32)}$. Por esta razón, el uso de la PCRa propuesta en este estudio es de gran importancia para una detección oportuna, rápida y confiable.

La alta sensibilidad de esta variante de PCR ya se ha demostrado en varias investigaciones. Se ha detectado una sensibilidad de hasta 10 pg en aislamientos de salmónidos a partir de muestras de ARN purificadas ${ }^{(34)}$. Lopez-Lastra et al ${ }^{(18)}$ desarrollaron una PCRa para detectar hasta 1 pg del VNPI en portadores asintomáticos a partir de muestras de campo. Suzuki et $a l^{(37)}$ desarrollaron una PCRa, utilizando un par de iniciadores basados en la detección de la región de unión de la secuencia del gen VP2/NS de los birnavirus acuáticos con una sensibilidad de un 1 fg (femtogramo) de genoma viral en la muestra.

La PCRa proporciona un aumento en la especificidad y reduce la detección de falsos positivos cuando el segundo par de iniciadores genera amplificación solo si el primer par desencadenó el fragmento de ADN esperado ${ }^{(21,34,42)}$. Otra ventaja de la PCRa propuesta en este estudio es la detección del virus de los tejidos infectados sin llevar a cabo el aislamiento en cultivo celular, ya que, aunque se considera la prueba de referencia para su diagnóstico, es una técnica que restringe su uso a laboratorios con personal capacitado para el manejo de las líneas celulares, el equipo necesario para su mantenimiento e incubación y la identificación del efecto citopático ${ }^{(7)}$. 
Se debe mencionar que se han propuesto otras variantes de PCR y pruebas, pero su adopción depende del equipo disponible en los laboratorios. Por ejemplo, Rodríguez et $a l^{(21)}$ realizaron una comparación de seis métodos de diagnóstico para el VNPI, en la que encontró que la RT-PCR y la citometría de flujo fueron los métodos más apropiados y sensibles para una detección rutinaria del VNPI. En otro estudio ${ }^{(23)}$ encontraron una sensibilidad baja (43\%) con el uso de una RT-PCR, por lo que se propusieron utilizar un protocolo corto de incubación en cultivo celular como técnica complementaria, adicional a una PCR múltiplex utilizando tres pares de iniciadores en una sola reacción para incrementar la probabilidad de identificar todos los serotipos del serogrupo A del VNPI, así como prevenir un resultado falso negativo. Aunque se han propuesto otras técnicas moleculares para un diagnóstico rápido y con alta sensibilidad como la RT-PCR en tiempo real y RT-LAMP (Loop-mediated isothermal amplification, por sus siglas en inglés), estas requieren equipos especializados y capacitación tanto para el diseño de iniciadores como para la interpretación de los resultados ${ }^{(22,42)}$. En México, el diagnóstico del VNPI se realiza principalmente mediante el aislamiento viral en cultivo celular y la detección de su genoma por RT-PCR en punto final, ya que esta técnica se lleva a cabo en la mayoría de los laboratorios de forma convencional.

Por otro lado, la detección del VNPI en los diferentes órganos analizados en este estudio confirma la amplia diseminación del virus. Usualmente los órganos recomendados para la detección del VNPI en cultivos celulares son: riñón, hígado, bazo y fluido ovárico del pie de cría o el alevín entero ${ }^{(7)}$. Sin embargo, el principal órgano blanco para la replicación es el riñón, donde el virus persiste ${ }^{(39)}$. A diferencia del riñón, otros órganos blancos para la detección del virus son el páncreas, el intestino, el hígado y las branquias. El páncreas se encuentra anatómicamente difuso entre los sacos pilóricos y en él se genera una severa necrosis. En el intestino se ha reportado una enteritis aguda caracterizada por la necrosis celular y glándulas que se encuentran en el tracto digestivo, responsable la eliminación del virus con las heces y el moco que se produce ${ }^{(6)}$. En el hígado, el VNPI induce marcadores de apoptosis, los cuales también se han encontrado en tejido intestinal y pancreático que corresponden a la acumulación viral y cambios patológicos en el tejido ${ }^{(43,44)}$. Finalmente, las branquias que son el órgano encargado del intercambio de oxígeno, pueden observarse pálidas debido al daño degenerativo y necrótico del epitelio. En este estudio, los órganos donde se encontró la mayor frecuencia de detección del virus fueron los sacos pilóricos, intestino y branquias, los cuales como se mencionó, han sido identificados como órganos blanco para la detección temprana de la enfermedad, puesto que son sitios de replicación temprana del virus ${ }^{(45)}$. 


\section{Conclusiones e implicaciones}

La PCRa utilizando iniciadores desarrollados para la identificación de aislamientos nacionales, es útil en el diagnóstico del VNPI, no solo en peces clínicamente enfermos, sino también para detectar peces infectados sin signos clínicos. Asimismo, se sugiere que ante un brote de la NPI en una unidad de producción, debe ser confirmada primero por este método. En casos necesarios, el aislamiento viral, estudios histopatológicos o inmunohistoquímicos, se recomiendan se lleven a cabo en los casos sospechosos o positivos a la PCRa.

\section{Agradecimientos}

Esta investigación se llevó a cabo con el apoyo financiero del Consejo Nacional de Ciencia y Tecnología (CONACyT) del proyecto CB -2009-01-134099. Catalina Tufiño Loza recibió el apoyo de CONACYT. Los autores también agradecen a A. Mejía, A. Fabián, J.C. Gómez de la Universidad del Valle de México (UVM) por su excelente asistencia técnica.

\section{Literatura citada:}

1. Rodríguez SJS, Borrego JJ, Perez PSI. Infectious pancreatic necrosis virus: biology, pathogenesis, and diagnostic methods. Adv Virus Res 2003;62(1):113-165.

2. Salgado-Miranda C. Necrosis pancreática infecciosa: enfermedad emergente en la truticultura de México. Vet Méx 2006;37(4):467-477.

3. Dobos P, Roberts TE. The molecular biology of infectious pancreatic necrosis virus: a review. Can J Microbiol 1983;29(4):377-384.

4. King AMQ, Adams MJ, Carstens EB, Lefkowitz EJ, King AMQ, et al, editors. Virus taxonomy: ninth report of the International Committee on Taxonomy of Viruses. New York, USA: Academic Press; 2012:499-507.

5. Dobos P. Birnaviruses. Encyclopedia of life sciences. Nature Publishing Group 2001, London.

6. Dhar A, LaPatra S, Orry A, Allnutt T. Infectious pancreatic necrosis virus. In: Woo PTK, Cipriano RC editors. Fish viruses and bacteria: Pathobiology and protection. 1rst ed. Wallingford, Oxfordshire, UK: CAB International; 2017: 1-12.

7. OIE. Manual of diagnostic tests for aquatic animals. 5th ed. Paris, France: World Organization for Animal Health. 2006. 
8. Munro ES, Midtlyng PJ. Infectious pancreatic necrosis and associated aquatic birnaviruses. In: Woo PT, Bruno DW, editors. Fish diseases and disorders. Volume 3: viral, bacterial and fungal infections, 2nd ed. Oxfordshire, UK: CABI; 2011:1-65.

9. Ortega SC, Montes de Oca R, Groman D, Yason C, Nicholson B, Blake S. Case report: viral infectious pancreatic necrosis in farmed Rainbow Trout from Mexico. J Aquat Anim Health 2002;14(4):305-310.

10. Salgado MC. Virulencia del virus de la necrosis pancreática infecciosa en trucha arcoíris (Oncorhynchus mykiss) a partir de aislamientos mexicanos [tesis doctorado]. México, DF: Universidad Nacional Autónoma de México; 2014.

11. Amos KH. Procedures for the detection and identification of certain fish pathogens, 3rd ed. Fish Health Section, American Fisheries Society, Corvallis; 1985.

12. Ahne W, Thomsen I. 1986. Infectious pancreatic necrosis: detection of virus and antibodies in rainbow trout IPNV-carrier (Salmo gairdneri). J Vet Med 1986;33(7):552-554.

13. Milne SA, Galachacher S, Cash P, Porter AJR. A reliable RTPCR-ELISA method for the detection of infectious pancreatic necrosis virus (IPNV) in farmed rainbow trout. J Virol Methods 2006;132(1-2):92-96.

14. Sanz F, Coll J. Techniques for diagnosing viral diseases of salmonid fish. Dis Aquat Org 1992;13:211-223.

15. LaPatra SE. The use of serological techniques for virus surveillance and certification of finfish. Annu Rev Fish Dis 1997;6:1-28.

16. Way-Shyan W, Yea-Ling W, Jainn-Shyan L. Single-tube, non-interrupted reverse transcription PCR for detection of IPNV. Dis Aquat Org 1997;28(3):229-233.

17. Pryde A, Melvin WT, Munro ALS. Nucleotide sequence analysis of the serotypespecific epitope of infectious pancreatic necrosis virus. Arch Virol 1993;129(1-4):287293.

18. Lopez-Lastra M, Gonzalez M, Jashes M, Sandino AM. A detection method for infectious pancreatic necrosis virus (IPNV) based on reverse transcription (RT)polymerase chain-reaction (PCR). J Fish Dis 1994;17(3):269-282.

19. Blake S, Lee MK, Singer J, McAllister PE, Nicholson BL. Detection and identification of aquatic birnavirus by polymerase chain reaction assay. J Clin Microbiol 1995;33(4):835-839. 
20. Alonso M, Rodríguez S, Pérez-Prieto SI. Viral coinfection in salmonids: infectious pancreatic necrosis virus interferes with infectious hematopoietic necrosis virus. Arch Virol 1999;144(4):657-673.

21. Rodriguez SJ, Borrego JJ, Perez-Prieto SI. Comparative evaluation of five serological methods and RT-PCR assay for the detection of IPNV in fish. J Virol Methods 2001;97(1-2):23-31.

22. Bowers RM, Lapatra SE, Dhar AK. Detection and quantitation of infectious pancreatic necrosis virus by real-time reverse transcriptase-polymerase chain reaction using lethal and non-lethal tissue sampling. J Virol Methods 2008;147(2):226-34.

23. Barrera-Mejía M, Simón-Martínez J, Salgado-Miranda C, Vega F, Ortega C, Aragón A. Development and validation of a short-time cell culture and multiplex reverse transcriptase polymerase chain reaction assay for infectious pancreatic necrosis virus in Mexican farm-sampled rainbow trout. J Aquat Anim Health 2009;21(3):167-72.

24. Tapia D, Eissler Y, Torres P, Jorquera E, Espinoza JC, Kuznar J. Detection and phylogenetic analysis of infectious pancreatic necrosis virus in Chile. Dis Aquat Org 2015;116(3):173-84.

25. Salgado-Miranda C, Rojas-Anaya E, García-Espinoza G, Loza-Rubio E. Molecular characterization of the VP2 gene of Infectious Pancreatic Necrosis Virus (IPNV) isolates from Mexico. J Aquat Anim Health 2014;26(1):43-51.

26. Dorson M, Touchy $\mathrm{C}$. The influence of fish age and water temperature on mortalities of rainbow trout, Salmo gairdneri Richardson, caused by a European strain of infectious pancreatic necrosis virus. J Fish Dis 1981;4(3):213-221.

27. de las Heras A, Perez-Prieto S, Rodríguez Saint-Jean S. In vitro and in vivo immune responses induced by a DNA vaccine encoding the VP2 gene of the infectious pancreatic necrosis virus. Fish Shellfish Immunol 2009;27(2):120-129.

28. Ingerslev HC, Fausa EP, Jakobsen RA, Petersen CB, Wergeland HI. Expression profiling and validation of reference gene candidates in immune relevant tissues and cells from Atlantic salmon (Salmo salar L.). Mol Immunology 2006;43(8):1194-1201.

29. Zar JH. Biostatistical analysis. 5th ed. New Jersey, USA: Prentice Hall; 2010.

30. Wolf K. Fish viruses and fish viral diseases. Ithaca, New York: Cornell University Press; 1988.

31. Smail DA, Bain N, Bruno DW, King JA, Thompson F, Pendrey DJ, Morrice S, Cunningham CO. Infectious pancreatic necrosis virus in Atlantic Salmon, Salmo salar L., post-smolts in the Shetland Isles, Scotland: virus identification, histopathology, 
immunohistochemistry and genetic comparison with Scottish mainland isolates. J Fish Dis 2006;29(1):31-41.

32. Ortega C, Valladares B, Arguedas D, Vega F, Montes de Oca R, Murray A. Distribution of infectious pancreatic necrosis virus (IPNV) based on surveillance programs in freshwater trout farms of Mexico. J Aquat Anim Health 2016;28(1):21-26.

33. Barrera-Mejía M, Martínez S, Ortega C, Ulloa-Arvizu R. Genotyping of infectious pancreatic necrosis virus isolates from Mexico state. J Aquat Anim Health 2011;23(4):200-206.

34. Alonso MC, Cano I, Castro D, Perez-Prieto SI, Borrego JJ. Development of an in situ hybridization procedure for the detection of sole Aquabirnavirus in infected fish cell cultures. J Virol Meth 2004;116(2):133-138.

35. Akhlagi M, Hosseini A. First report on the detection of infectious pancreatic necrosis virus (IPNV) by RT-PCR in rainbow trout fry cultured in Iran. Bull Eur Ass Fish Pathol 2007;27(5):205-210.

36. Taksdal T, Ramstad A, Stangeland K, Dannevig BH. Induction of infectious pancreatic necrosis (IPN) in covertly infected Atlantic salmon Salmo salar L. post-smolts by stress exposure, by injection of IPN virus (IPNV) and by cohabitation. J Fish Dis 1998;21(3):193-204.

37. Suzuki S, Hosono N, Kusuda R. Detection of aquatic birnavirus gene from marine fish using a combination of reverse transcription and nested PCR. Mar Biotechnol 1997;5(4):205-209.

38. Taksdal T, Dannevig BH, Rimstad E. Detection of infectious pancreatic necrosis (IPN)-virus in experimentally infected Atlantic salmon parr by RT-PCR and cell culture isolation. Bull Eur Ass Fish Pathol 2001;21(5):214-219.

39. Ørpetveit I, Mikalsen AB, Sindre H, Evensen $\varnothing$, Dannevig BH, Midtlyng PJ. Detection of infectious pancreatic necrosis virus in subclinically infected Atlantic salmon by virus isolation in cell culture or real-time reverse transcriptase polymerase chain reaction: influence of sample preservation and storage. J Vet Diagn Invest 2010;22(6):886-895.

40. Gahlawat SK, Munro ES, Ellis AE. A non-destructive test for the detection of IPNV carriers in Atlantic halibut Hippoglossus hippoglossus (L.). J Fish Dis 2004;27(4):233239. 
41. Rimstad E, Hornes E, Olsvik O, Hyllseth B. Identification of a double-stranded RNA virus by using polymerase chain reaction and magnetic separation of the synthesized DNA segments. J Clin Microbiol 1990;28(10):2275-2278.

42. Soliman H, Midtlyng PJ, El-Matbouli M. Sensitive and rapid detection of infectious pancreatic necrosis virus by reverse transcription loop mediated isothermal amplification. J Virol Methods 2009;158(1-2):77-83.

43. Imajoh M, Hirayama T, Oshima S. Frequent occurrence of apoptosis is not associated with pathogenic infectious pancreatic necrosis virus (IPNV) during persistent infection. Fish Shellfish Immunol 2005;18(2):163-177.

44. Santi N, Sandtrø A, Sindre H, Song H, Hong JR et al. Infectious pancreatic necrosis virus induces apoptosis in vitro and in vivo independent of VP5 expression. Virology 2005;342(1):13-25.

45. Shankar KM, Yamamoto T. Prevalence and pathogenicity of infectious pancreatic necrosis virus (IPNV) associated with feral lake trout, Salvelinus namaycush (Walbaum). J Fish Dis 1994;17(5):461-471. 